\title{
Study on Mechanical Properties of the Composite Resin Matrix Fiber Reinforced
}

Min Wen, JiXiang Luo

Faculty of Civil and Architectural Engineering, Nanchang Institute of Technology

Nanchang Jiangxi 330099, China E-mail: 16320576@qq.com; E-mail: 48260308@qq.com

Fiber reinforced polymer Resin matrix composites have the good performance, and it is widely used in various fields to release the impact load. Therefore, the study of stress and strain characteristics is quite useful to in providing the reliable basis for the structural design. The tensile test is one of the important methods to detect the mechanic property of the material, which can be used to observe the deformation behavior of the material. Reinforced materials are often added to improve the mechanical properties of the composites, and characteristics and mechanical properties of composite materials will be obvious anisotropic. Damage behavior of resin matrix composite material with fiber reinforced is complex, and mechanical properties of it are quite difficult to obtain just through the experiments, so the finite element method becomes a useful tool to get the mechanical properties. In this paper, we developed the conventional finite element method to investigate the mechanical properties of composites material. The verification proves that the modified finite element method can get much accurate results.

Keywords: Mechanical property; Composites; Resin based material; Fiber reinforced.

\section{References}

[1] MOHD AZLAN MOHD AZUAN, ABDUL LATIF MUHAMAD RIDZUAN, ABDULLAH MOHAMAD ZAKI, ZAINAL ABIDIN KAMAL ARIF, ABDUL WAHAB AZMI. (2013). Flow behavior in the resin infusion of glass fiber reinforced polymer wind turbine blade. Advanced Materials Research, 686, pp. 118-124.

[2] LU YUAN, MEI SHUANG, PI PI-HUI, HAN TAILIANG, CHENG JIANG, WEN XIU-FANG, CAI ZHI-QI, QIAN YU. (2014). One-dimensional heat transfer study of a fiber-reinforced wind epoxy composite system in vacuum assisted resin transfer molding process. Polymer Composites, 35(6), pp. 1031-1037.

[3] PITARRESI GIUSEPPE, ALESSI SABINA, TUMINO DAVIDE, NOWICKI ANDRZEJ, SPADARO GIUSEPPE. (2014). Interlaminar fracture toughness behavior of electron-beam cured carbon-fiber reinforced epoxy-resin composites. Polymer Composites, 35(8), pp. 1529-1542.

[4] HU HONGLIN, HAO LIFENG, WANG RONGGUO, LIU WENBO, YANG FAN, JIAO WEICHENG, XU ZHONGHAI. (2014). Tensile properties of epoxy with microcapsules and imidazoline derivatives curing agent and interlaminar self-healing properties of carbon fiber reinforced epoxy composites. Polymers and Polymer Composites, 22(3), pp. 293-298.

[5] SUBAGIA I.D.G.ARY, JIANG ZHE, TIJING LEONARD D., KIM YONJIG, KIM CHEOL SANG, LIM JAE KYOO, LIM JAE KYOO. (2014). Hybrid multi-scale basalt fiber-epoxy composite laminate reinforced with Electrospun polyurethane nanofibers containing carbon nanotubes. Fibers and Polymers, 15(6). pp. 1295-1302.

[6] XU YANHUA, YUAN XINLIN, WANG NI, LIU ZHAOLIN. (2014). Comparison of bending properties Cowoven-knitted and Multi-layered biaxial Weft-knitted fabric reinforced composites. Fibers and Polymers, 15(6), pp. 1288-1294.

[7] ZHANG WEI, KANAKUBO TOSHIYUKI. (2014). Local bond stress-slip relationship between carbon fiber-reinforced polymer plates and concrete under fatigue loading. ACI Structural Journal, 111(4), pp. 955-965.

[8] RUSNAKOVA, S., FOJTL, L., ZALUDEK, M., RUSNAK, V. (2014). Design of Material Composition and Technology Verification for Composite Front End Cabs. Manufacturing Technology, 14(4) , pp. 607-611

[9] HAFIZAH N.A.K., BHUTTA M.A.R., JAMALUDIN M.Y., WARID M.H., ISMAIL M., RAHMAN M.S., YUNUS I., AZMAN M. (2014).Kenaf fiber reinforced polymer composites for strengthening RC beams. Journal of Advanced Concrete Technology, 12(6), pp. 167-177.

[10] LIANG MENG, WU ZHI-MIN, UEDA TAMON, ZHENG JIAN-JUN, AKOGBE ROMUALD. (2012). Experiment and modeling on axial behavior of carbon fiber reinforced polymer confined concrete cylinders with different sizes. Journal of Reinforced Plastics and Composites Manufacturing Technology, 31(6), pp. 389-403.

[11] NOVAKOVA-MARCINCINOVA, L., NOVAK-MARCINCIN, J. (2014).Production of ABS-Aramid Composite Material by Fused Deposition Modeling Rapid Prototyping System. Manufacturing Technology, 14(1), pp. 85-91

[12] ZHANG RUI, HE LINGFENG, LI CHANGRONG. (2011). The stress intensity factor of opening mode determined by digital image correlation. Applied Mechanics and Materials, 83, pp. 54-59. 
[13] SASAKI SYUUTEI, EZUMI TSUTOMU. (2005).Experimental analysis of stress intensity factor of a high polymer having a crack and a circular hole or an inclusion by tensile load. Proceedings of SPIE - The International Society for Optical Engineering, 5852 PART II, pp. 832-837.

[14] HUISMAN R., HEUVEL, H.M. (1984).Relations of the Mechanical Properties of Synthetic Fibers and FiberReinforced Materials, Respectively, and the Physical Structure of the Fiber. Muanyag Es Gumi/Plastics and Rubber, 21(7), pp. 206-211.

[15] CHEN GANG, DU ZHAO FANG, LI ZHEN, SONG WEI MIN. (2013). Analysis of mechanical properties and exploration of failure mechanism for nonwoven reinforced composites. Advanced Materials Research, 791, pp. 480-485.

[16] CZIGÁNY, T., PÖLÖSKEI, K., KARGER-KOCSIS, J. (2005). Fracture and failure behavior of basalt fiber matreinforced vinylester/epoxy hybrid resins as a function of resin composition and fiber surface treatment. Journal of Materials Science, 40(21), pp. 5609-5618.

[17] CHEON SEONG BONG, BEPPU MASUHIRO, SONODA YOSHIMI, ITOH MASAHARU. (2014).Failure behavior and numerical simulation of the local damage of ultra-high strength fiber reinforced concrete subjected to high velocity impact. Applied Mechanics and Materials, 566, pp. 205-210.

[18] FITOUSSI JOSEPH, BOCQUET MICHEL, MERAGHNI FODIL. (2013).Effect of the matrix behavior on the damage of ethylene-propylene glass fiber reinforced composite subjected to high strain rate tension. Composites Part B: Engineering, 45(1), pp. 1181-1191.

[19] MOHAMADI M.R., MOHANDESI J AGHAZADEH, HOMAYONIFAR M. (2013).Fatigue behavior of polypropylene fiber reinforced concrete under constant and variable amplitude loading. Journal of Composite Materials, 47(26), pp. 3331-3342.

[20] HARADA YOSHIHISA, MURAMATSU MAYU, SUZUKI TAKAYUKI, NISHINO MICHITERU, NIINO HIROYUKI. (2014). Influence of laser process on mechanical behavior during cutting of carbon fiber reinforced plastic composites. Advanced Materials Research, pp. 783-786: 1518-1523.

[21] SHI DONGYANG, GUAN HONGBO, GONG WEI. (2014). High accuracy analysis of the characteristic-nonconforming FEM for a convection-dominated transport problem. Mathematical Methods in the Applied Sciences, 37(8), pp. 1130-1136.

[22] ZMINDÁK, M., MESKO, J., PELAGIC, Z., ZRAK, A. (2014). Finite Element Analysis of Crack Growth in Pipelines. Manufacturing Technology, 14(1), pp. 116-122.

[23] BARANGER THOURAYA N., JOHANSSON B. TOMAS, RISCHETTE ROMAIN. (2013) .On the Alternating Method for Cauchy Problems and Its Finite Element Discretisation. Springer Proceedings in Mathematics and Statistics, 48, pp. 183-197.

[24] BELLIS CÉDRIC, BONNET MARC. (2013).Qualitative identification of cracks using 3D transient elastodynamic topological derivative: Formulation and FE implementation. Computer Methods in Applied Mechanics and Engineering, 253, pp. 89-105.

[25] LI RUI-XIONG, CHEN WU-JUN, FU GONG-YI. (2012). Experimental and stowing/deploying dynamical simulation of lenticular carbon fiber reinforced polymer thin-walled tubular space boom. Journal of Shanghai Jiaotong University (Science), 17(1), pp. 58-64.

[26] GU XINGYU, DONG QIAO. (2012). Laboratory test and numerical simulation of bond performance between basalt fiber reinforced polymer rebar and concrete. Journal of Testing and Evaluation, 40(7).

[27] HASSANm A. M., DOUGLAS J. F., GARBOCZI, E. J. (2014). Computational modeling of the electromagnetic characteristics of carbon fiber-reinforced polymer composites with different weave structures. AIP Conference Proceedings, 1581 33, pp. 1494-1499.

[28] PETR VALÁSEK, MIROSLAV MÜLLER. (2012). Ploymeric particle composites with fillers saturated matrix. Manufacturing Technology, 12(4), pp. 272-276.

[29] PARK JAI-WOO, YEOM HEE-JIN, YOO JUNG-HAN. (2013). Axial loading tests and FEM analysis of slender square hollow section (SHS) stub columns strengthened with carbon fiber reinforced polymers. International Journal of Steel Structures, 13(4), pp. 731-743. 